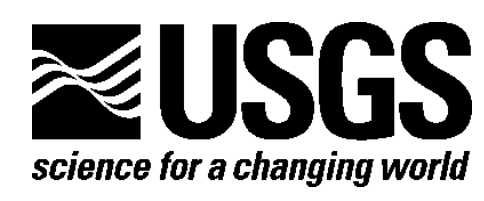

\title{
Field Survey and Damage Assessment of the Mineral, Virginia, Earthquake of August 23, 2011
}

Open-File Report 2012-1198 
This page intentionally left blank 


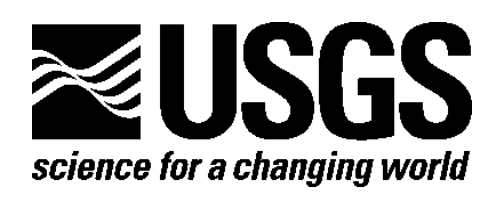

\section{Field Survey and Damage Assessment of the Mineral, Virginia, Earthquake of August 23, 2011}

By Helen R. Thomas and Katharine Turkle

Open-File Report 2012-1198 


\section{U.S. Department of the Interior \\ SALLY JEWELL, Secretary}

\section{U.S. Geological Survey \\ Suzette M. Kimball, Acting Director}

U.S. Geological Survey, Reston, Virginia: 2013

For more information on the USGS-the Federal source for science about the Earth,

its natural and living resources, natural hazards, and the environment-visit

http://www.usgs.gov or call 1-888-ASK-USGS

For an overview of USGS information products, including maps, imagery, and publications,

visit $h$ ttp://www.usgs.gov/pubprod

To order this and other USGS information products, visit $h$ ttp://store.usgs.gov

Suggested citation:

Thomas, H.R., and Turkle, K., 2013, Field survey and damage assessment of the Mineral, Virginia, earthquake of August 23, 2011: U.S. Geological Survey Open-File Report 2012-1198, 20 p.,

http://pubs.usgs.gov/of/2012/1198/.

Any use of trade, firm, or product names is for descriptive purposes only and does not imply endorsement by the U.S. Government.

Although this information product, for the most part, is in the public domain, it also may contain copyrighted materials as noted in the text. Permission to reproduce copyrighted items must be secured from the copyright owner. 


\section{Contents}

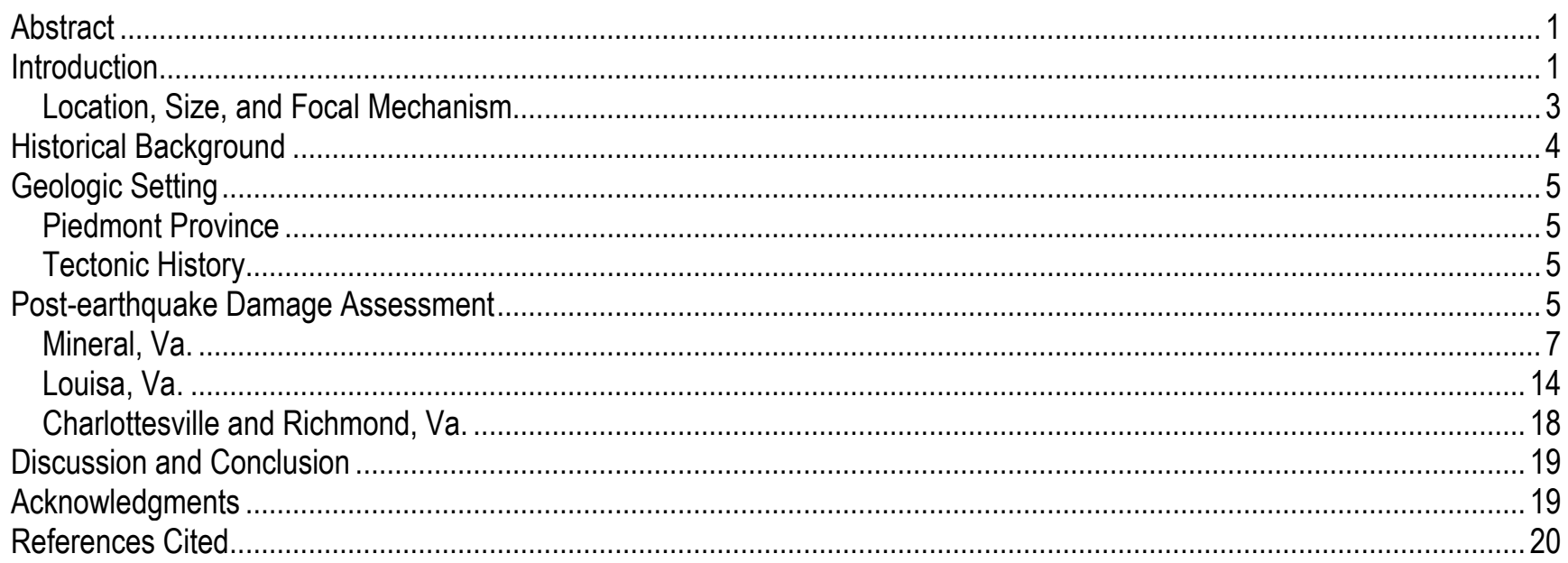

\section{Figures}

1. Map showing location of the August 23, 2011, magnitude $\left(M_{w}\right) 5.8$ Mineral, Virginia, earthquake within the Piedmont Province.....

2. Generalized seismic hazard map of the Eastern United States ..................................................................

3. Moment tensor diagram for the August 23, 2011, Mineral, Virginia, earthquake epicenter ......................................4

4. Map of specific locations of buildings that were photographed and assessed for damage from the August 23, 2011, magnitude $\left(M_{\mathrm{w}}\right) 5.8$ Mineral, Virginia, earthquake .....

5. Community Internet intensity map of the August 23, 2011, magnitude $\left(M_{w}\right) 5.8$ Mineral, Virginia, earthquake epicenter and surrounding area

6. Photograph of the brick façade of the U.S. Post Office in Mineral, Virginia, which collapsed during the August 23, 2011, Mineral, Virginia, earthquake.

7. Photograph of a fallen ceiling panel in the local Mineral, Virginia, grocery store after August 23, 2011, Mineral, Virginia, earthquake.

8. Photograph of one of several large floor cracks in the local Mineral, Virginia, grocery store after the August 23, 2011, Mineral, Virginia, earthquake.

9. Photograph of a crack in the basement of a Mineral, Virginia, residence after the August 23, 2011, Mineral, Virginia, earthquake.

10. Photograph of broken upper chimney under blue tarp at a Mineral, Virginia, residence after the August 23, 2011, Mineral, Virginia, earthquake

11. Photograph of chimney repairs beginning on a Mineral, Virginia, residence 7 days after the initial shock of the August 23, 2011, Mineral, Virginia, earthquake.

12. Photograph of a cracked brick wall at a Mineral, Virginia, residence after the August 23, 2011, Mineral, Virginia, earthquake.

13. Photograph of cracks in the interior drywall of a Mineral, Virginia, residence after the August 23, 2011, Mineral, Virginia, earthquake.

14. Photograph of a Louisa, Virginia, residence with a collapsed chimney after the August 23, 2011, Mineral, Virginia, earthquake.

15. Photograph of a Louisa, Virginia, residence with cracked walls after the August 23, 2011, Mineral, Virginia, earthquake.

16. Photograph of the Louisa, Virginia, residence shown in figure 15

17. Photograph of a brick wall of a Louisa, Virginia, residence after the August 23, 2011, Mineral, Virginia, earthquake. 
This page intentionally left blank 


\title{
Field Survey and Damage Assessment of the Mineral, Virginia, Earthquake of August 23, 2011
}

Helen R. Thomas ${ }^{1}$ and Katharine Turkle ${ }^{2}$

\begin{abstract}
The town of Mineral, Virginia (Va.), underwent an M=5.8 earthquake on August 23, 2011. A U.S. Geological Survey team was sent to visually inspect and document the damage in the cities of Richmond, Charlottesville, Louisa, and Mineral, Va. Our inspection concluded that the Modified Mercalli Intensity rating of moderate (V) to very strong (VII) is consistent with the expected and observed damage at these locations. Louisa County, Va., sustained the most extensive damage. We photographed fallen chimneys, collapsed walls, and cracked foundations. From visual inspection of the above-listed locations, this report catalogs the range and extent of damage from the August 23, 2011, earthquake for future reference and analysis.
\end{abstract}

\section{Introduction}

At 17:51 UTC (1:51 p.m. EDT) on August 23, 2011, a magnitude $\left(M_{\mathrm{w}}\right) 5.8$ earthquake occurred in central Virginia (Va.), 61 kilometers $(\mathrm{km})$ northwest of Richmond and $135 \mathrm{~km}$ southwest of Washington, D.C. (fig. 1). This earthquake was the largest on the eastern seaboard since the $M_{\mathrm{w}}=5.9$ event of 1897 and the largest on the east coast since the Charleston, SC, $M_{\mathrm{w}}=6.9$ earthquake of 1886. The August 23, 2011 earthquake occurred within the Central Virginia Seismic Zone (CVSZ; fig. 2), one of two areas of frequent seismicity in Virginia. No fatalities were reported from the earthquake. Several buildings and residences in the towns of Mineral and Louisa, located within the immediate epicentral area, were considerably damaged. In contrast, the more distant cities of Richmond and Charlottesville sustained little to no damage. This report summarizes the results of a field survey of the earthquake impacts 1 week after the event, and discusses the tectonic and geologic background for this seismic activity. The level of damage observed was comparable to expected results based on groundmotion data and instrumental intensity in the region surrounding Richmond, Charlottesville, Mineral, and Louisa, Va. (fig. 1).

\footnotetext{
${ }^{1}$ National Association of Geoscience Teachers (NAGT) U.S. Geological Survey intern 2012.

${ }^{2}$ U.S. Geological Survey contractor.
} 


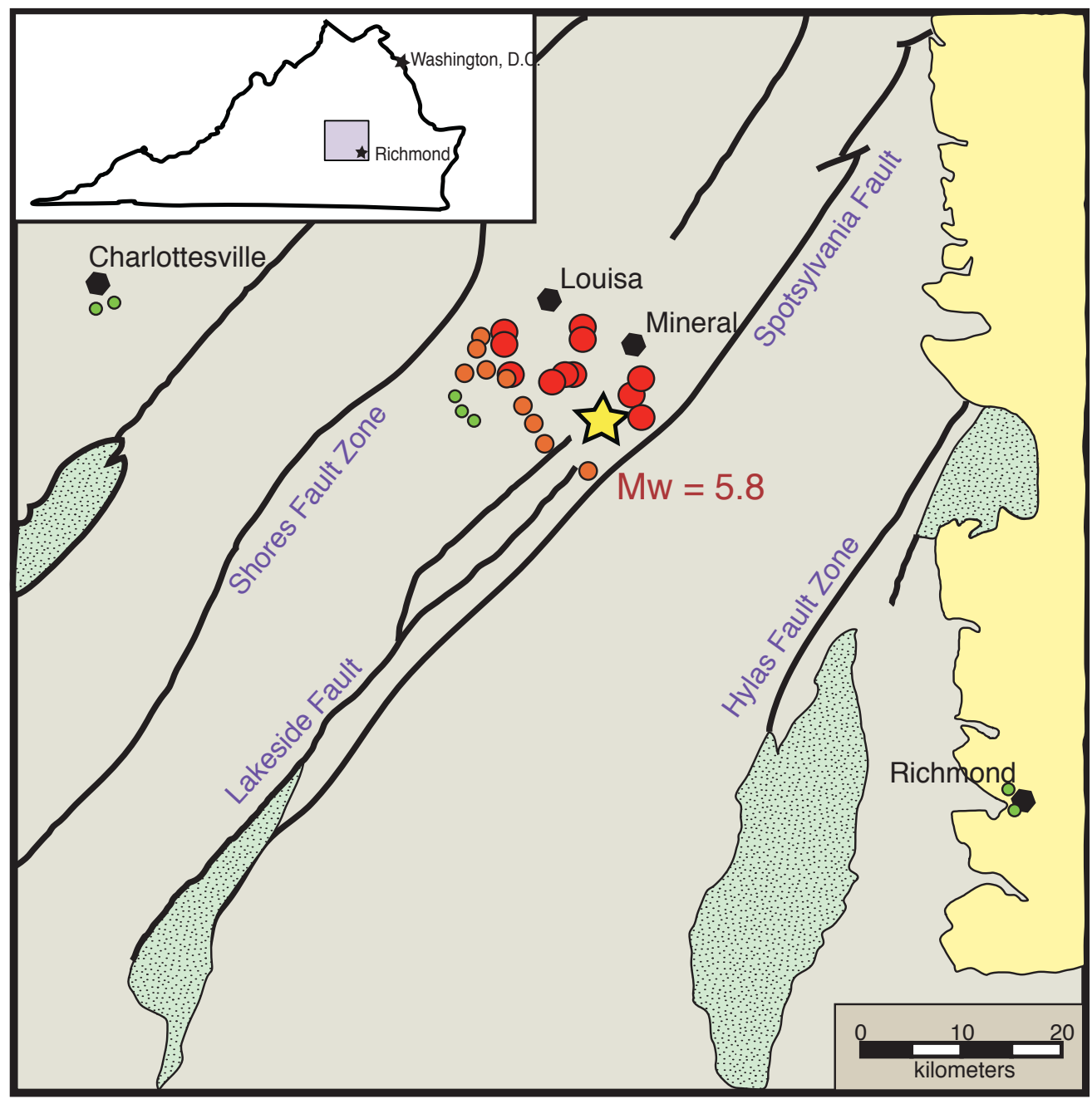

\section{Assessment Sites}

$\underbrace{M=5.8}_{\text {August 23, } 2011}$

MMI VII

O MMI VI

- MMI V
Bedrock Geology

Coastal Plain Province: Cenozoic Sediments

* sand, silt, clay

Mesozoic rift basins

* arkose, sandstone, siltstone, shale

Piedmont Province: Proterozoic and Paleozoic rocks * igneous and metamorphic rocks

Figure 1. Map showing location of the August 23, 2011, magnitude $\left(M_{\mathrm{w}}\right) 5.8$ Mineral, Virginia, earthquake within the Piedmont Province. Damage assessment locations are shown classified by Modified Mercalli Intensity (MMI) scale.

Earthquakes in stable continental regions (SCRs) are infrequent but at times can be more damaging than those along plate boundaries. The reasons are twofold: (1) structures and buildings in these regions generally are not built to withstand seismic motions from large earthquakes (Crone and others, 2003); and (2) the attenuation of seismic energy from large earthquakes is relatively low in plate interiors (Hanks and Johnston, 1992), causing these events to be felt over a wide area. The Mineral, Va., earthquake was felt across the Eastern United States and caused noticeable damage in areas a considerable distance away from the epicenter, such as in Washington, D.C., where stone ornaments on the National Cathedral collapsed. 


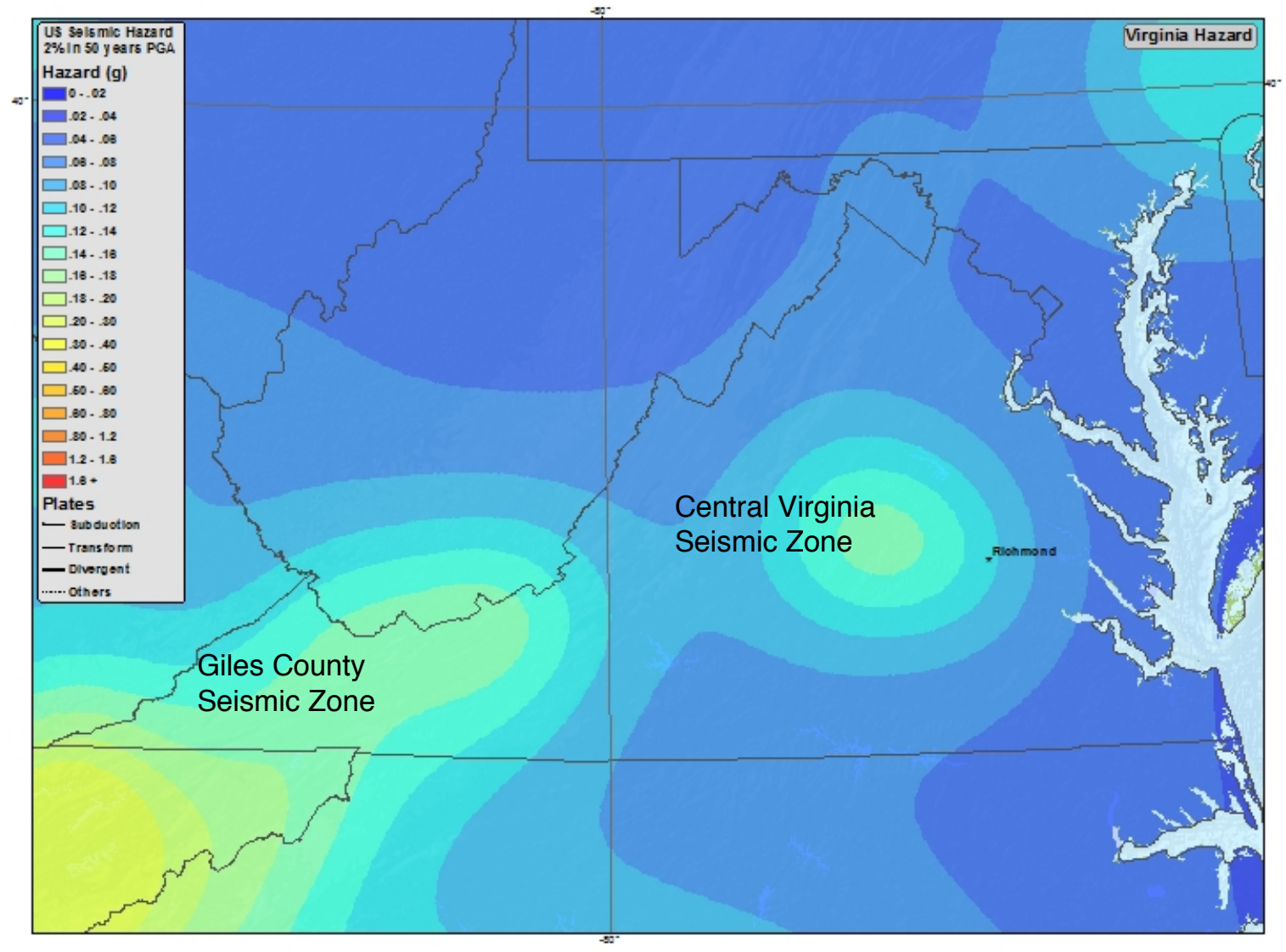

Figure 2. Generalized seismic hazard map of the Eastern United States. Both the Central Virginia Seismic Zone and the Giles County Seismic Zone are shown in this figure. Modified from U.S. Geological Survey (2012).

\section{Location, Size, and Focal Mechanism}

The main shock epicenter was located at latitude $37.936^{\circ} \mathrm{N}$., longitude $77.933^{\circ} \mathrm{W} ., 8 \mathrm{~km}$ southwest of Mineral in Louisa County, Va. (fig. 1); the hypocentral depth was $6 \mathrm{~km}$ (fig. 3). The main shock occurred as predominantly reverse faulting on a north-northeast-striking plane (see http://earthquake.usgs.gov/earthquakes/eqarchives/fm/se082311a_rmt.php, October 2011) within the CVSZ (fig. 2). 


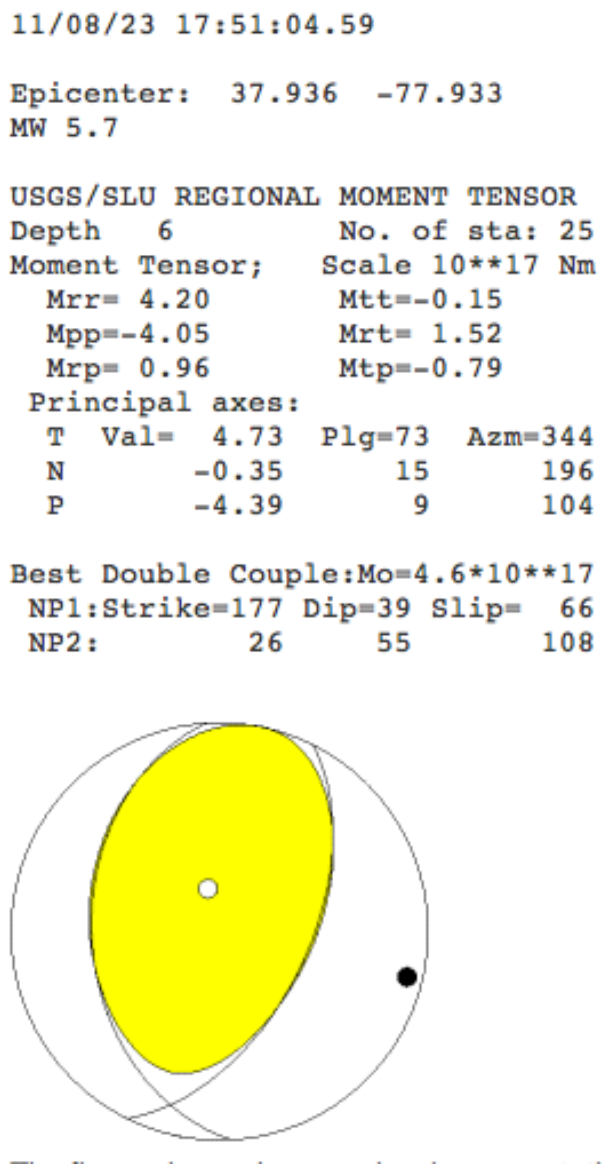

Figure 3. Moment tensor diagram for the August 23, 2011, Mineral, Virginia, earthquake epicenter (U.S. Geological Survey, 2011b).

\section{Historical Background}

Most seismicity in the contiguous United States is concentrated in the West, where an active strike-slip boundary exists between the North American and Pacific tectonic plates, including extensional tectonics in the Basin and Range. In contrast, the Eastern United States has much lower seismic activity because the nearest plate boundary lies 3,000 km away at the Mid-Atlantic Ridge. However, distinct zones along the east coast are defined by higher amounts of seismicity. The New Madrid Seismic Zone (NMSZ), for example, is a well-studied region in the Southeastern United States where three highly damaging earthquakes $\left(M_{\mathrm{w}}>7.0\right)$ occurred from December 1811 to February 1812 (fig. 2). The three earthquakes were among the largest ever to strike eastern North America and were followed by hundreds of aftershocks that lasted for decades (Johnston and Schweig, 1996).

Two seismic zones have been identified in Virginia: the Giles County Seismic Zone (GCSZ) and the CVSZ (fig 2). Several damaging earthquakes have occurred in these zones, including the Mw $=5.6$ event of 1897 in the GCSZ, and the Mw=4.8 event of 1875 in the CVSZ. The August 23, 2011, earthquake occurred in the CVSZ near its northeast edge, in an area of moderate seismic hazard (fig. 2). The CVSZ is situated in the Piedmont physiographic province of Virginia between Richmond and Charlottesville. The CVSZ is structurally complex, containing several major shear zones, dikes, plutons, and synforms/antiforms (Earthquake Engineering Research Institute, 2011). Major earthquakes could occur along several faults and shear zones in the CVSZ, such as the Chopawamsic Fault, the Lakeside Fault, and the Spotsylvania Shear Zone (fig. 1). 


\section{Geologic Setting}

\section{Piedmont Province}

The east-central United States is divided into five physiographic regions: the Appalachian Plateau province, the Valley and Ridge province, the Blue Ridge province, the Piedmont province, and the Coastal Plain province. In Virginia, the Piedmont province is the largest, consisting of Proterozoic metamorphic rocks overlain by Paleozoic igneous rocks (Hatcher, 2005).

\section{Tectonic History}

The Piedmont province of the east-central United States is the remnant of several tectonic events, beginning with the Grenville Orogeny at 1.2 Ga, when North America and Africa were sutured together. Metamorphosed granite batholiths in the Blue Ridge province are remnants of this orogeny. At $\sim 570 \mathrm{Ma}$, the opening of the Proto-Atlantic Ocean began, and a divergent continental plate boundary existed until $440 \mathrm{Ma}$, when the Taconic Orogeny occurred. During this orogeny, a volcanic island arc collided with southwestern Virginia and created a mountain range in the western Piedmont region. The Acadian Orogeny followed in the Devonian at $345 \mathrm{Ma}$, and a second mountain range in the Piedmont province was uplifted. Finally, during the Alleghenian Orogeny at $310 \mathrm{Ma}$, Africa collided with North America, forming the Appalachian Mountains of today. At about $190 \mathrm{Ma}$, convergence ceased, and the Atlantic Ocean began to open along the Mid-Atlantic Ridge (Hatcher, 2005).

Today, the eastern United States lies in an SCR of the North American tectonic plate. Globally, approximately half of the earthquakes in SCRs occur on reactivated faults that are associated with ancient continental-interior rifts and paleorifted margins (Schulte and Mooney, 2005). SCR earthquakes in the Eastern United States may occur on either reactivated thrust faults associated with orogenic events or on reactivated extensional faults associated with rifting of the Atlantic Ocean beginning at $190 \mathrm{Ma}$ (Schulte and Mooney, 2005).

\section{Post-earthquake Damage Assessment}

We conducted a field survey of earthquake damage in the epicentral area (fig. 4) 6 days after the August 23, 2011, earthquake. We viewed and photographed damage in the towns of Mineral and Louisa, Va., and collected eyewitness accounts in Mineral, Louisa, Richmond, and Charlottesville. This report focuses on the extent and characteristics of damage to buildings and infrastructure in those towns. 


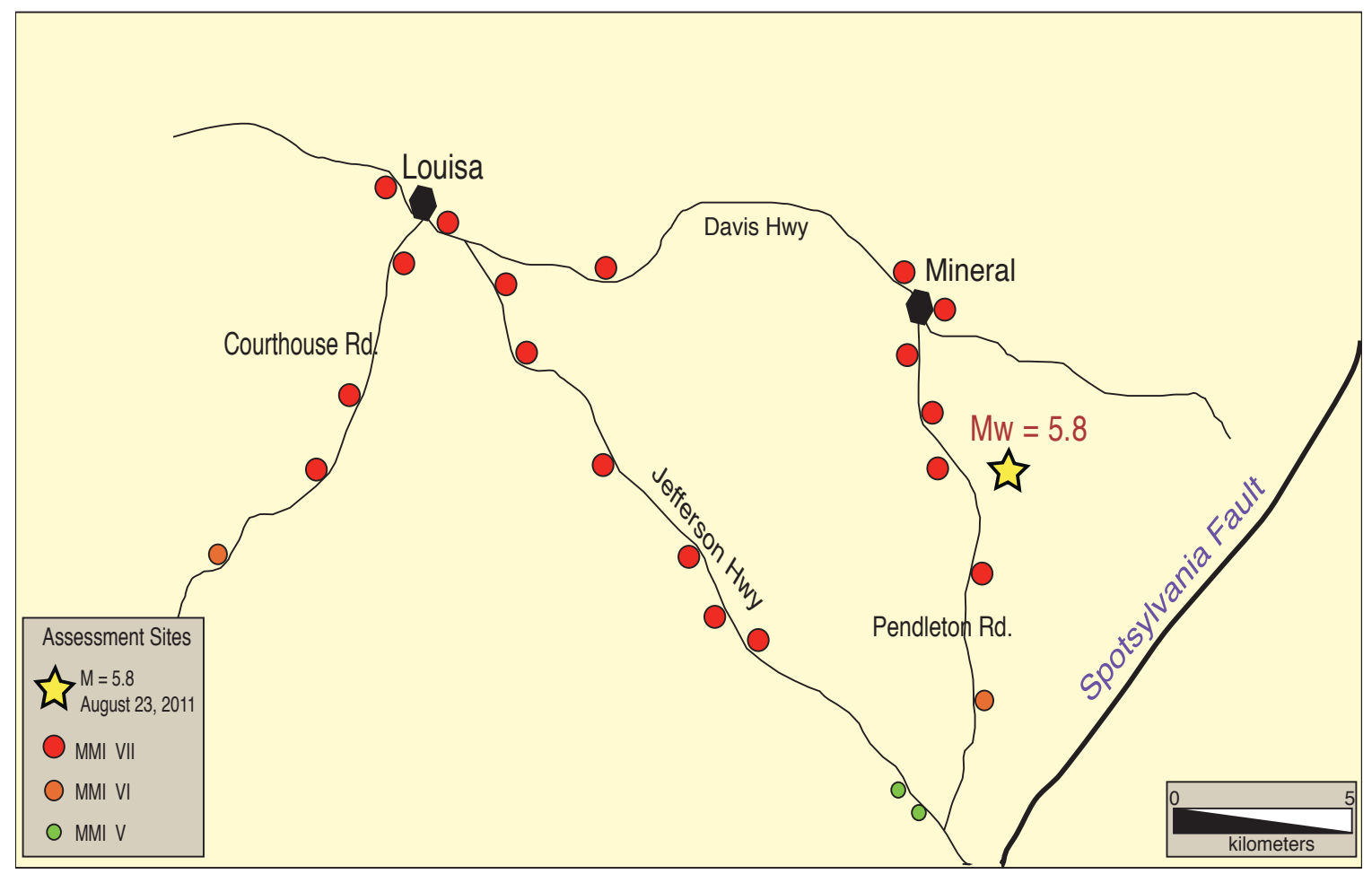

Figure 4. Map of specific locations of buildings that were photographed and assessed for damage from the August 23, 2011, magnitude $\left(M_{\mathrm{w}}\right) 5.8$ Mineral, Virginia, earthquake near Charlottesville, Richmond, Mineral, and Louisa, Virginia. The locations of the photographs selected for this document are labeled. MMI, Modified Mercalli Intensity.

The U.S. Geological Survey (USGS)'s "Did You Feel It?” map of the epicentral area and surrounding region (fig. 5) highlights areas in which the most damage was expected. The documented damage was correlated to specific intensity descriptions on the Modified Mercalli Intensity (MMI) scale (fig. 5). The actual damage was visually inspected and paired to the corresponding MMI. Earthquake damage was assessed in three different locations: the Richmond metropolitan area, the Charlottesville metropolitan area, and Louisa and Mineral Counties, Va. (fig. 5). 


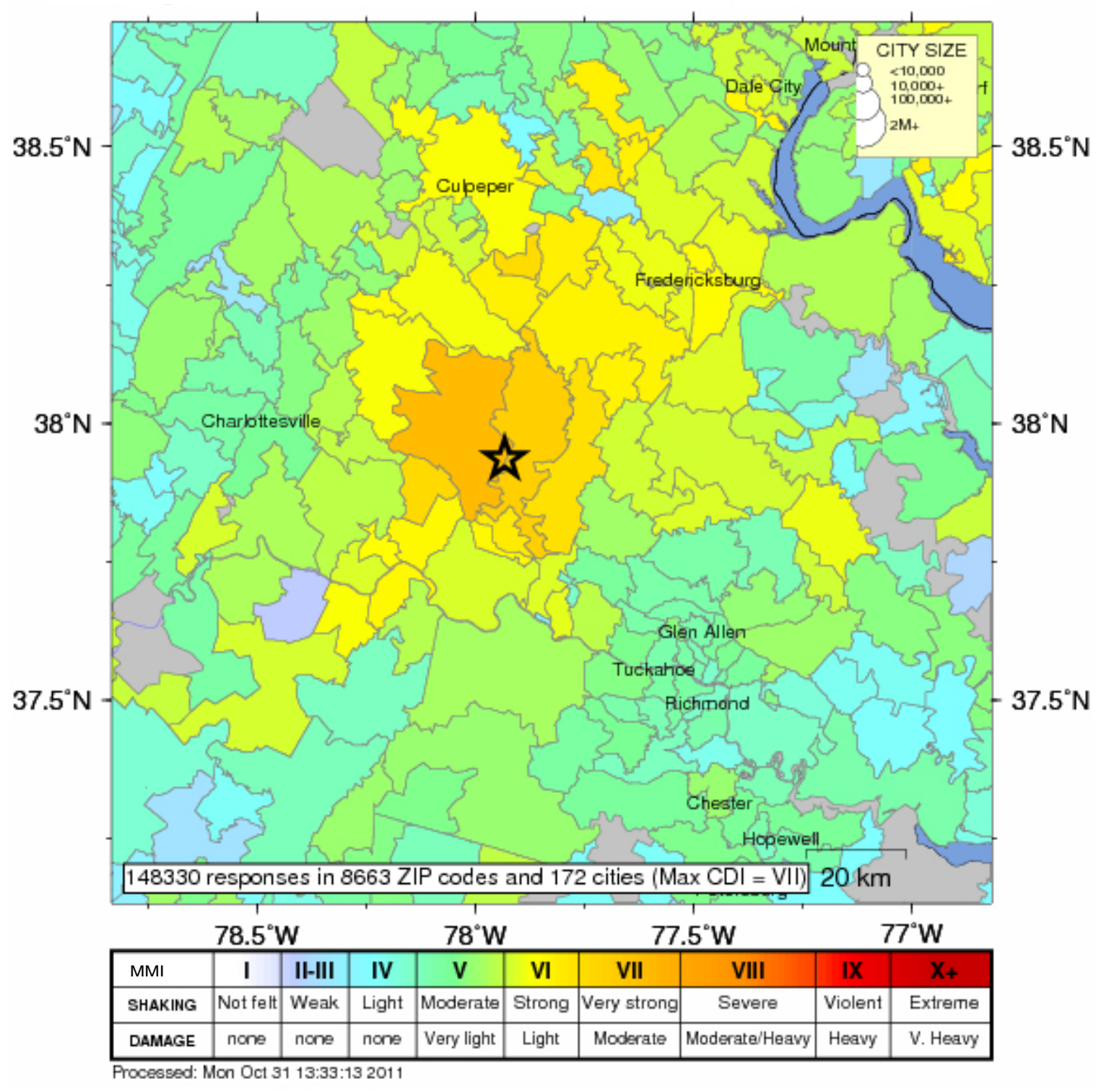

Figure 5. Community Internet intensity map of the August 23,2011 , magnitude $\left(M_{\mathrm{w}}\right) 5.8$ Mineral, Virginia, earthquake epicenter and surrounding area. At this scale Mineral and Louisa, Virginia, are located under the black star on this map. Modified from U.S. Geological Survey (2011a).

\section{Mineral, Va.}

The town of Mineral, Va., sustained the most damage from the earthquake. Approximately 70 percent of the structures in downtown and rural Mineral were damaged (Louisa County Fire Department, oral commun., August 2011), including the local high school, post office, grocery store, and many residences. All the buildings that sustained damage were constructed of either unreinforced masonry or brick with concrete foundations. After the earthquake, the high school was closed for repairs (Mineral High School superintendent, oral commun., August 2011). The post office sustained severe damage, losing one of its brick-and-glass façades (fig. 6). Several ceiling panels in the grocery store fell down, and the floor was cracked along its entire length (figs. 7, 8). 


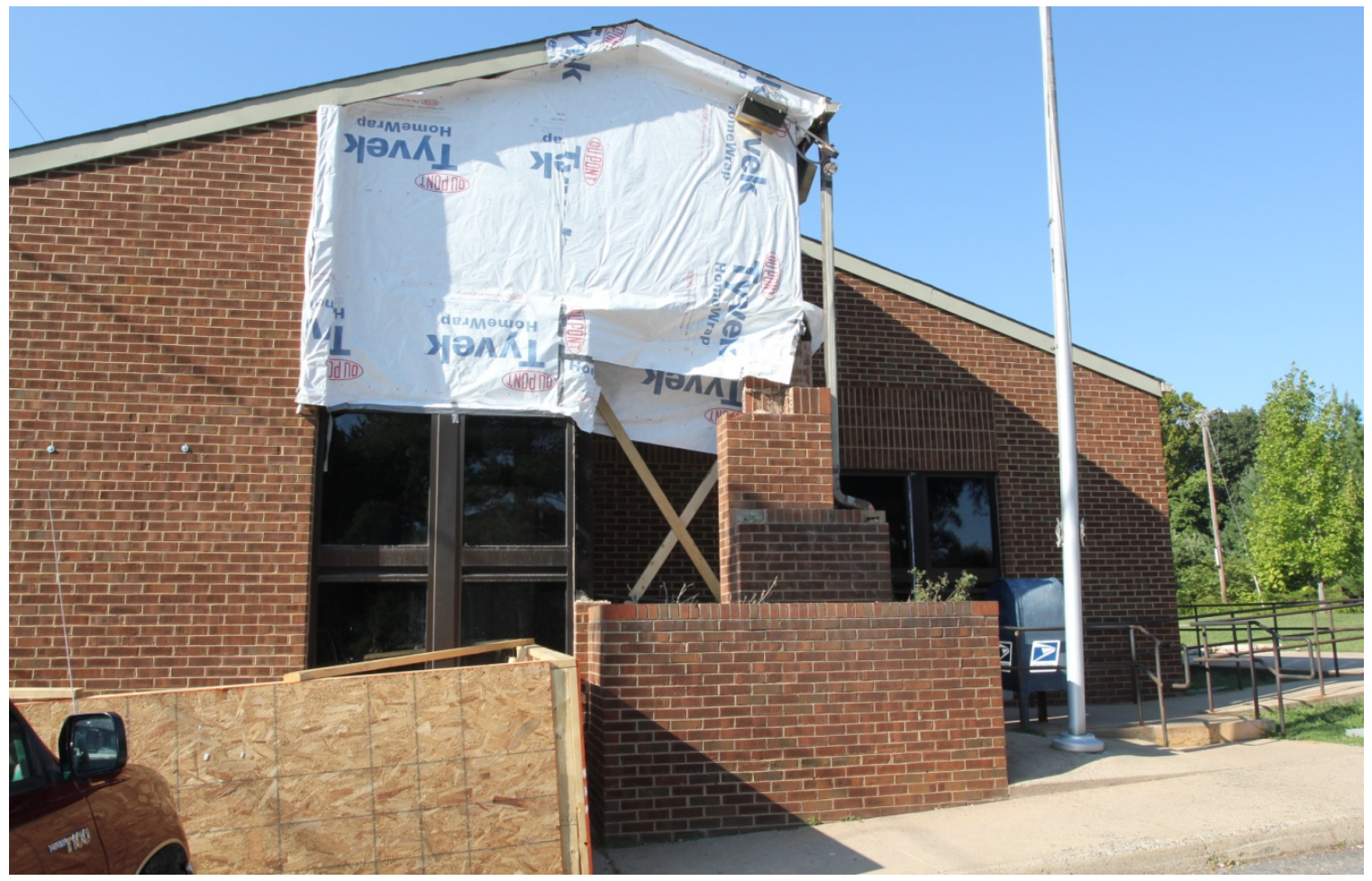

Figure 6. Photograph of the brick façade of the U.S. Post Office in Mineral, Virginia, which collapsed during the August 23, 2011, Mineral, Virginia, earthquake.

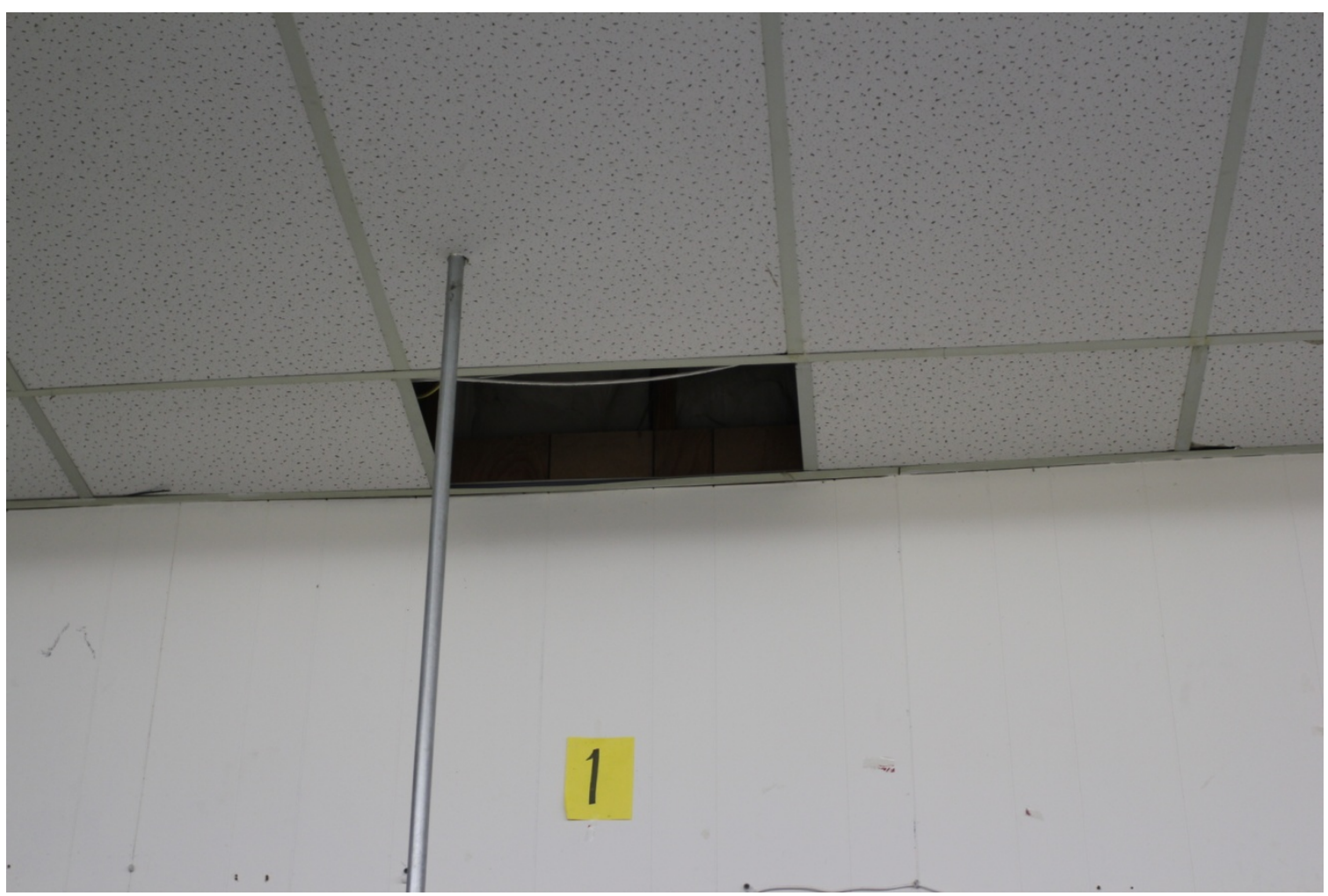

Figure 7. Photograph of a fallen ceiling panel in the local Mineral, Virginia, grocery store after August 23, 2011, Mineral, Virginia, earthquake. 


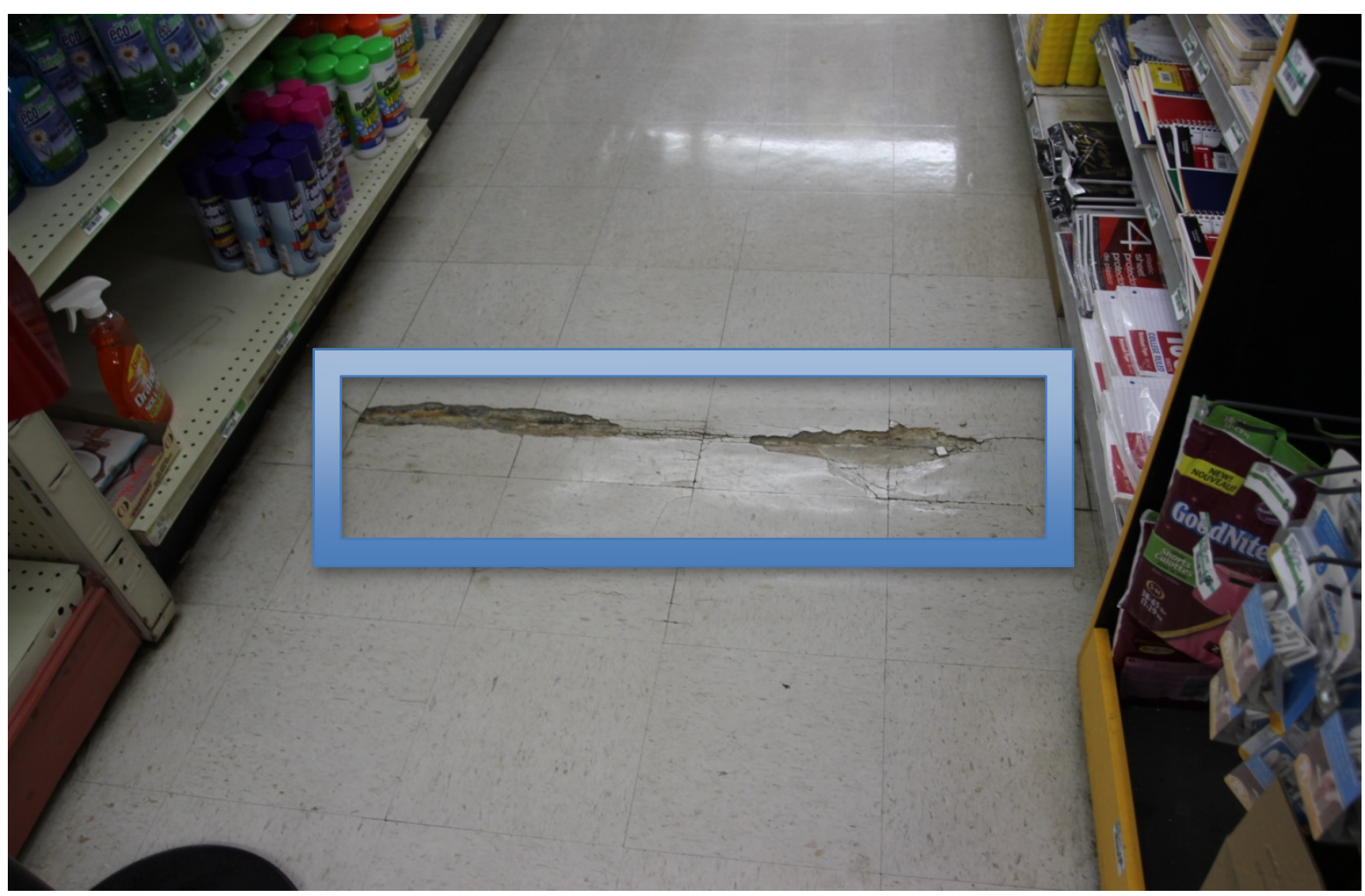

Figure 8. Photograph of one of several large floor cracks (outlined by blue rectangle) in the local Mineral, Virginia, grocery store after August 23, 2011, Mineral, Virginia, earthquake.

One residence outside of downtown Mineral was significantly damaged: the foundation was cracked, the chimneys were damaged, and the windows and walls were bowed away from their framework (figs. 9-12). Aftershocks continued to exacerbate the damage for as long as 2 weeks after the main shock. We spoke with several residents in the town of Mineral who pointed out fresh cracks on the walls of their houses that began the day before we arrived ( 8 days after the earthquake) and continued into the next week. Signs and mailboxes were tilted, and stop-sign poles were displaced by several centimeters along Main Street (fig. 13). 


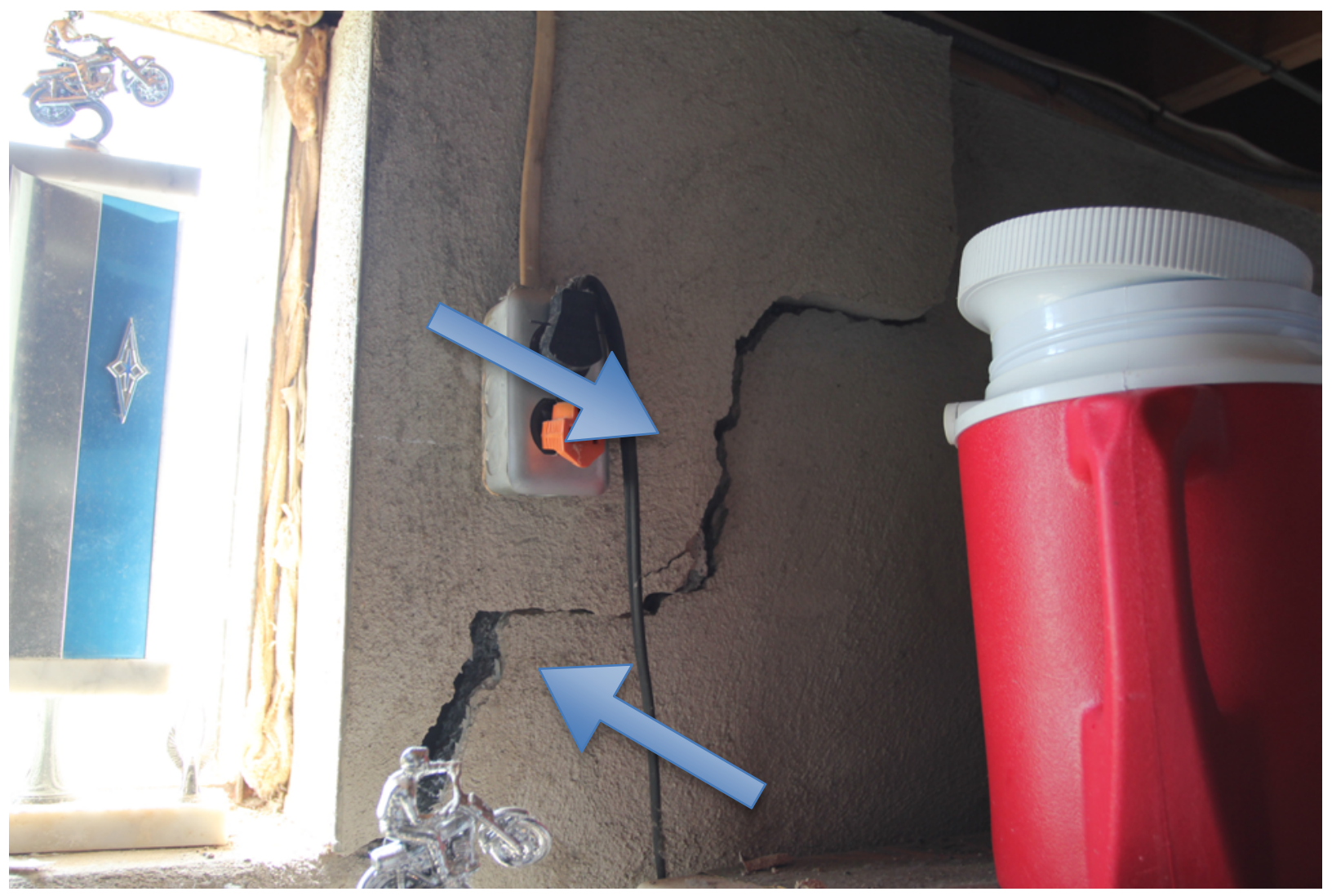

Figure 9. Photograph of a crack in the basement of a Mineral, Virginia, residence after the August 23, 2011, Mineral, Virginia, earthquake. Image shows "stair-stepping" (bottom left to upper right) under the electrical outlet, approximately 0.5 meters visible here. 


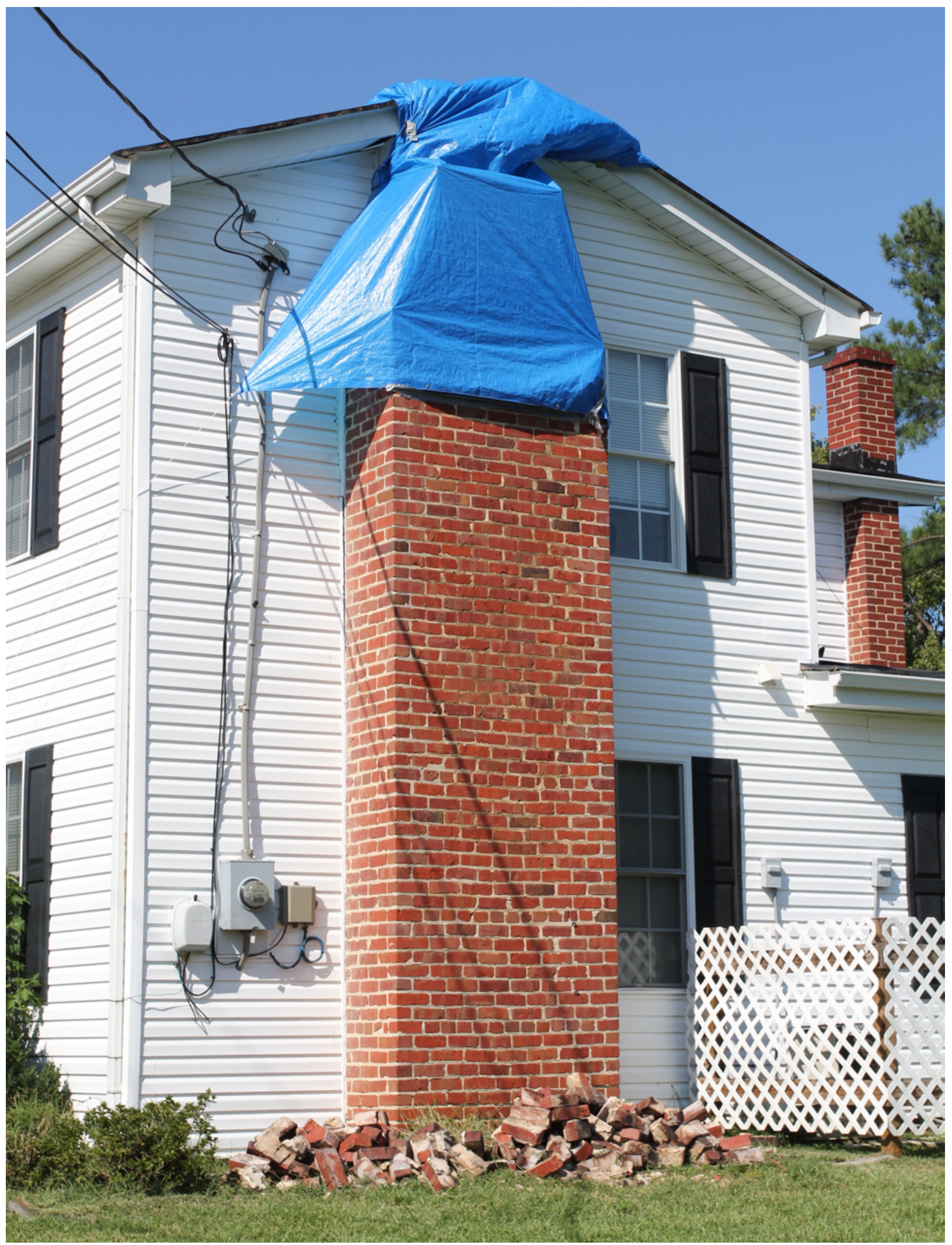

Figure 10. Photograph of broken upper chimney under blue tarp at a Mineral, Virginia, residence after the August 23, 2011, Mineral, Virginia, earthquake. Note the chimney in the right side of the background does not have any visible damage. 


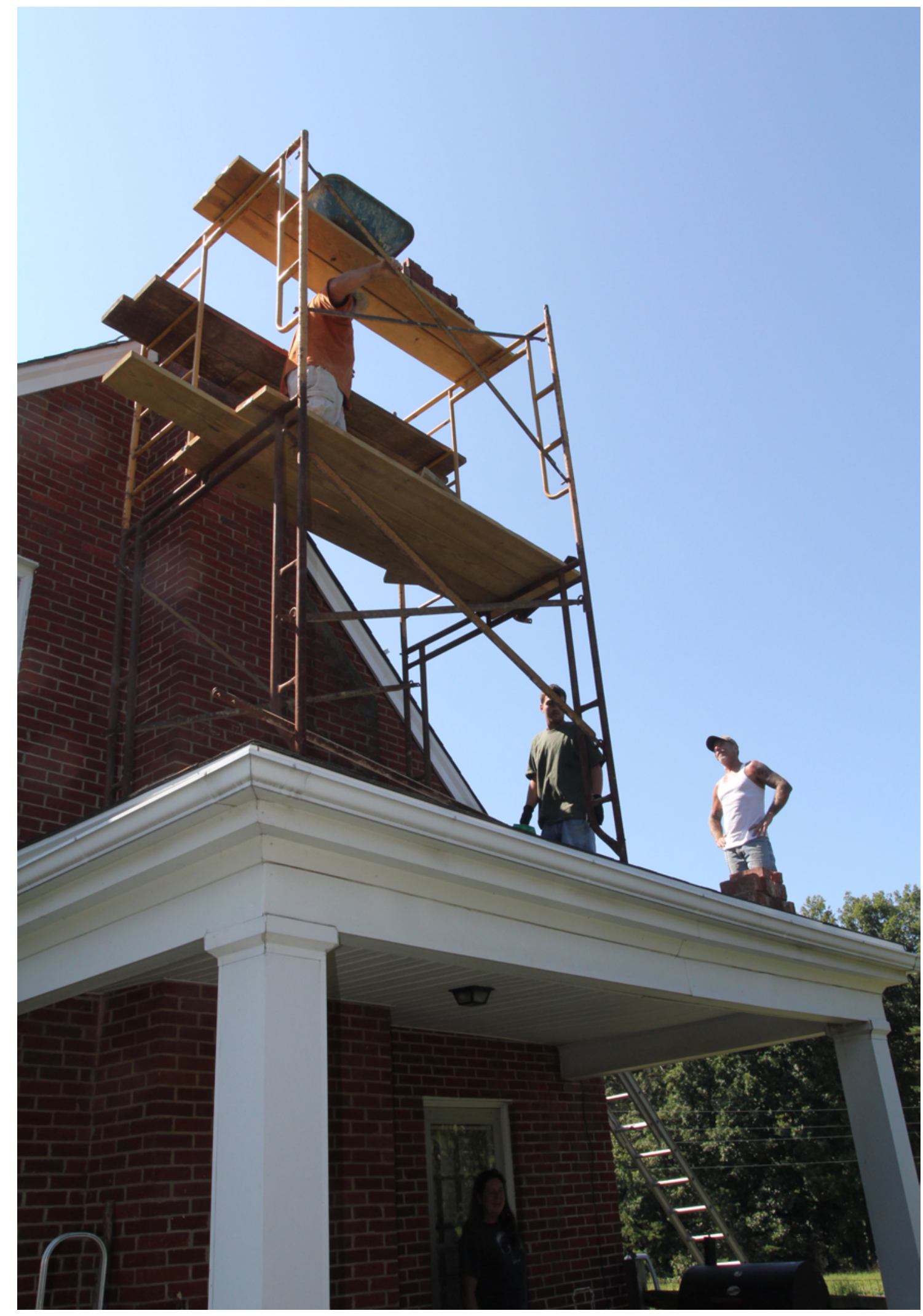

Figure 11. Photograph of chimney repairs beginning on a Mineral, Virginia, residence 7 days after the initial shock of the August 23, 2011, Mineral, Virginia, earthquake. 


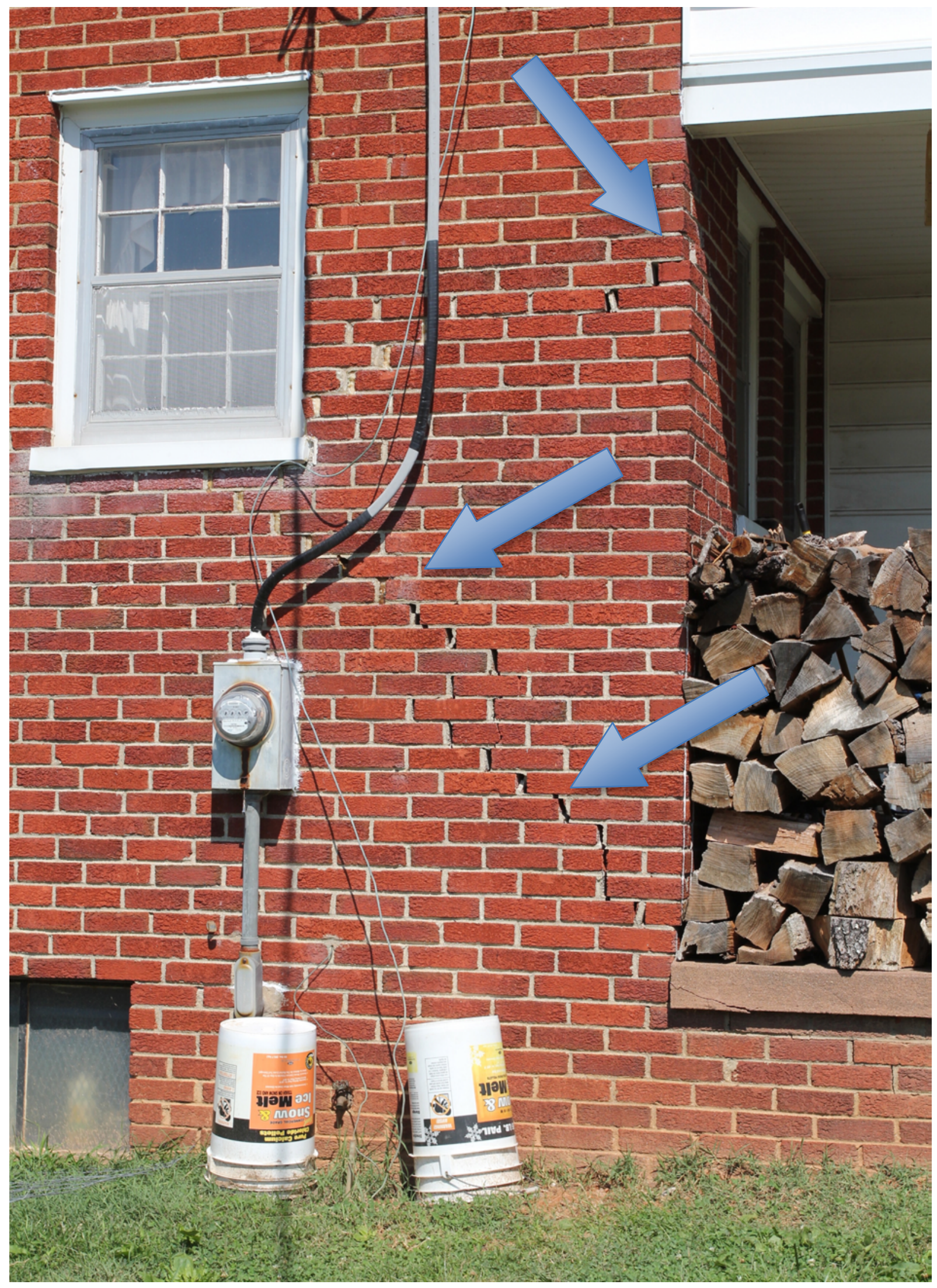

Figure 12. Photograph of a cracked brick wall at a Mineral, Virginia, residence after the August 23, 2011, Mineral, Virginia, earthquake. 


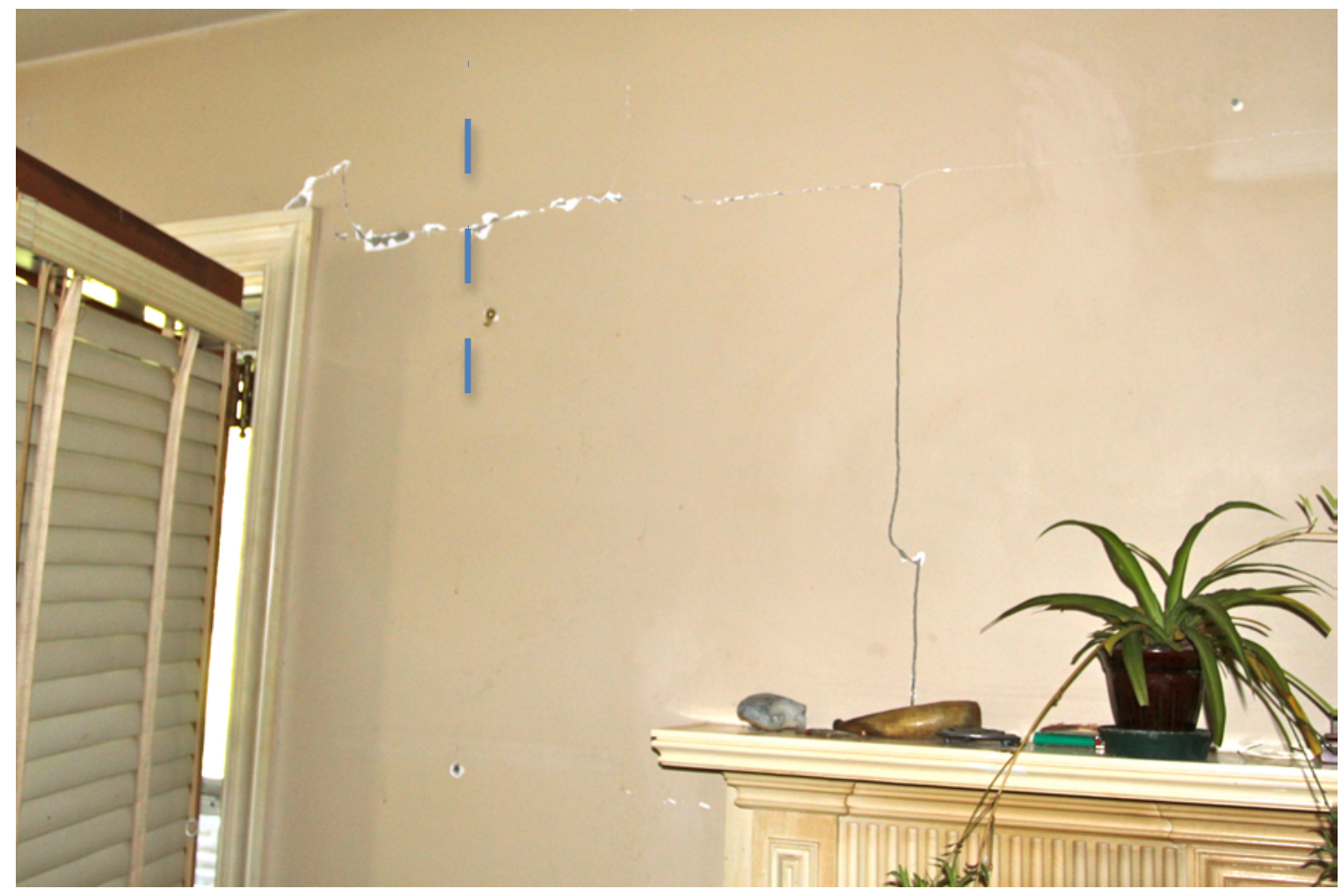

Figure 13. Photograph of cracks in the interior drywall of a Mineral, Virginia, residence after the August 23, 2011, Mineral, Virginia, earthquake. The initial shock caused the crack to extend from the corner of the doorframe to the blue dashed line. All of the cracks emanated to the right and down. Cracks to the right of the blue dashed line occurred during aftershocks. Photograph taken 8 days after initial shock.

\section{Louisa, Va.}

The town of Louisa, Va., also sustained considerable damage from the earthquake. Rural residences sustained most of the damage, including fallen chimneys, cracked foundations, and deformed brick walls (figs. 14-17). Approximately 60 percent of the buildings in Louisa County were significantly damaged (Louisa County Fire Department, oral commun., August 2011). Overall, the county was assigned a MMI of at least VI (strong), as illustrated by several destroyed or partially destroyed brick chimneys. Residents reported glasses, plates, books, and other items falling off shelves and heavy furniture being moved. Cracks formed in the walls of Louisa County High School, and six students sustained minor injuries there (Louisa County High School superintendent, oral commun., August 2011).

Inspections by local fire departments revealed that approximate 60 homes sustained major to severe damage and 120 homes were mildly to moderately damaged as a result of the earthquake (Louisa County Fire Department, oral commun., August 2011). Total property damage in Louisa County was estimated at over $\$ 70$ million (Times-Dispatch Staff, 2011). 


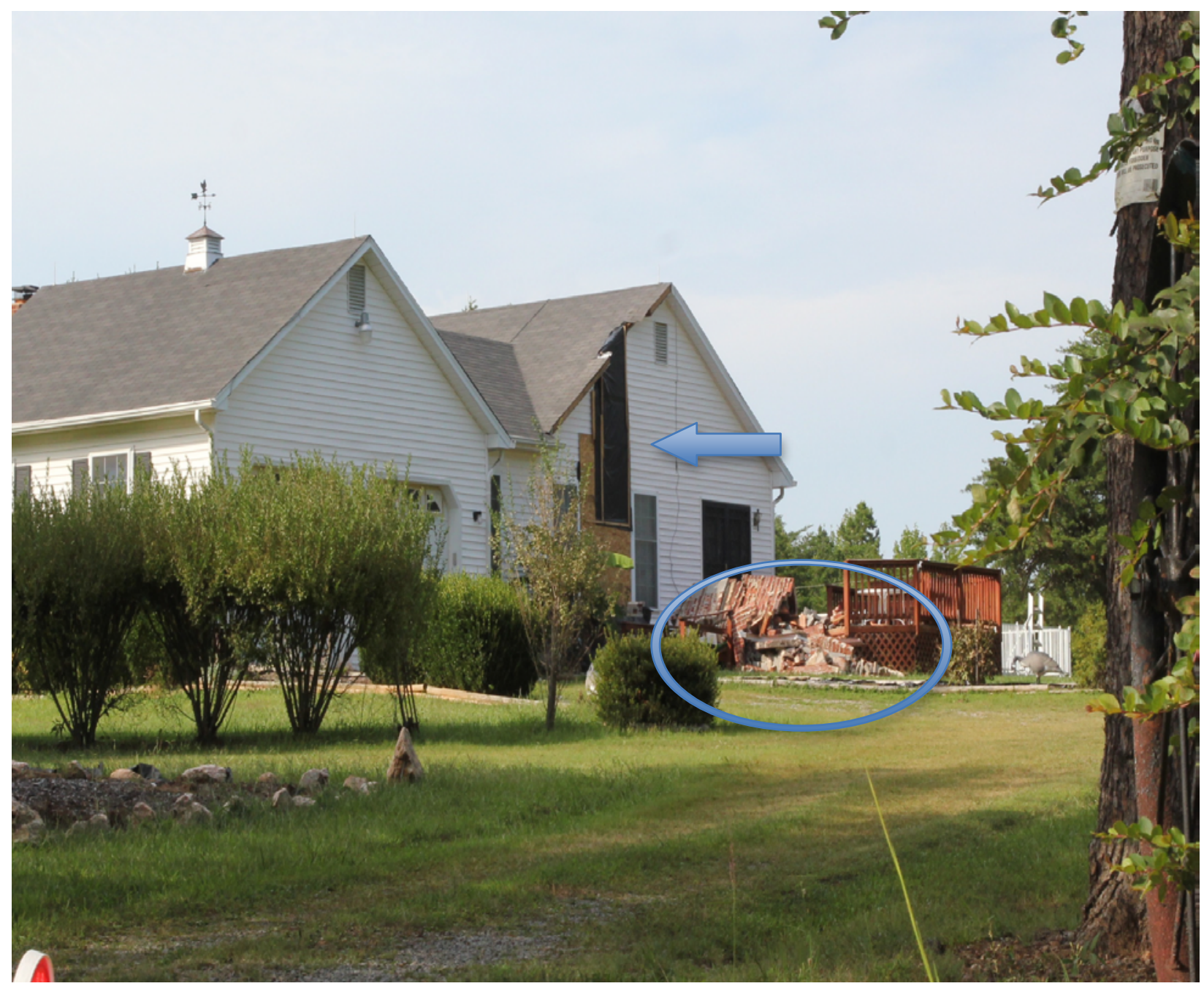

Figure 14. Photograph of a Louisa, Virginia, residence with a collapsed chimney after the August 23, 2011, Mineral, Virginia, earthquake. Arrow indicates the exposed black tarpaper on the side of this house where the chimney stood before the earthquake. The oval indicates the pile of rubble left after the chimney fell down. 


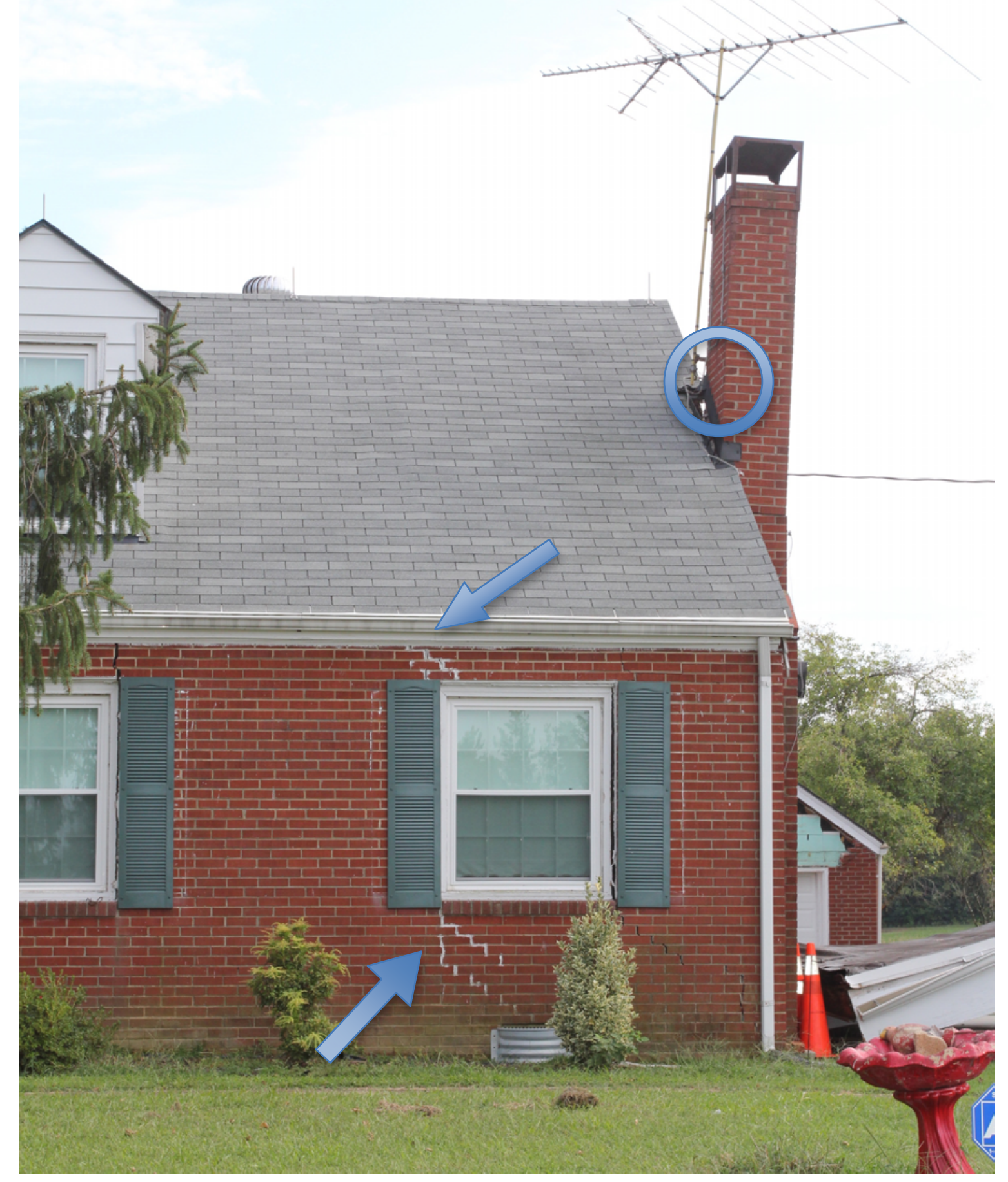

Figure 15. Photograph of a Louisa, Virginia, residence with cracked walls after the August 23, 2011, Mineral, Virginia, earthquake. Blue arrows point at the white cracks stair-stepping along the wall and circle indicates the gap from the leaning chimney; separations from the roof can be seen as the white light between roof and chimney. 


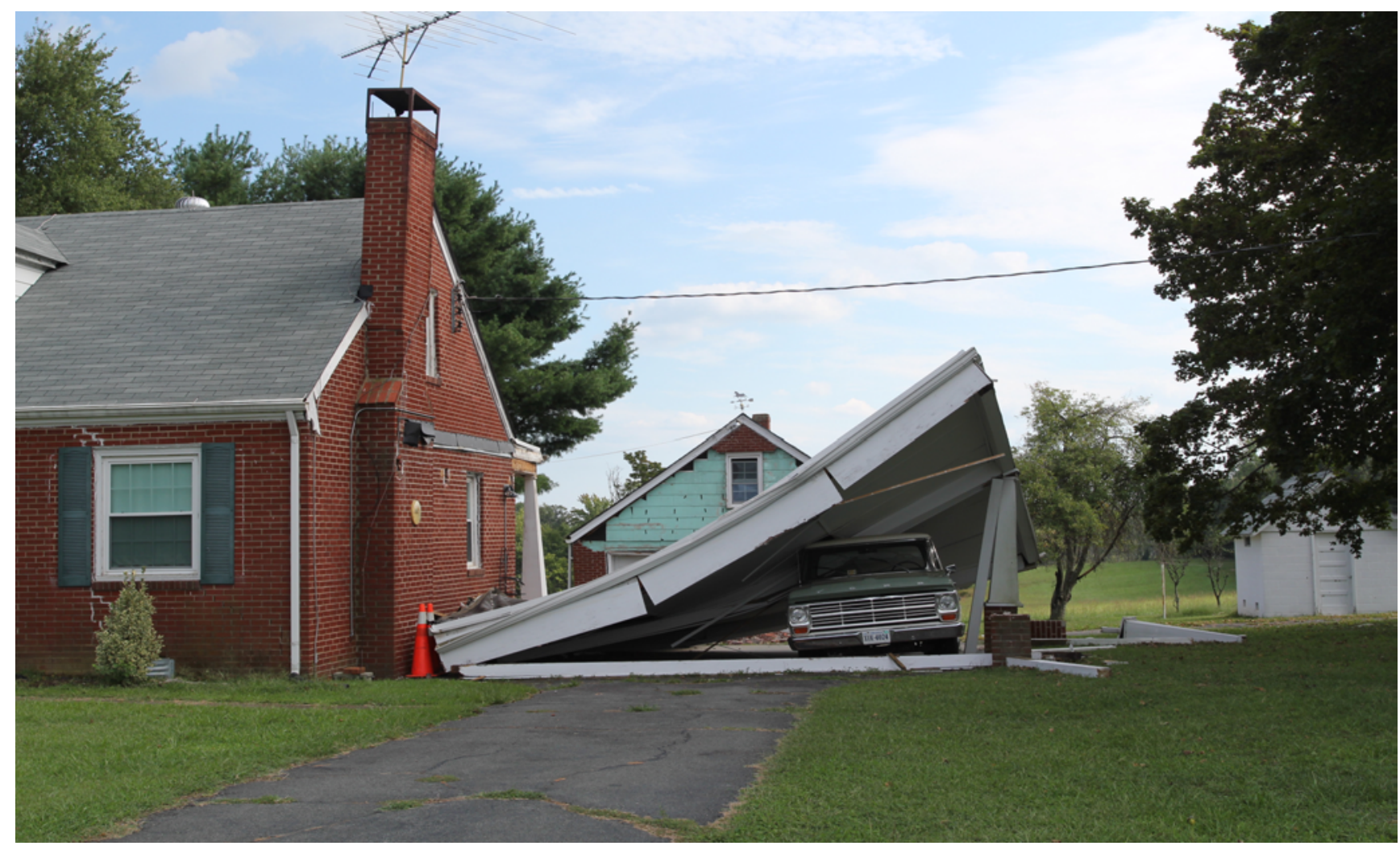

Figure 16. Photograph of the Louisa, Virginia, residence shown in figure 15. The carport shown in the image detached from the house and collapsed as a result of the August 23, 2011, Mineral, Virginia, earthquake, crushing the vehicle underneath it. 


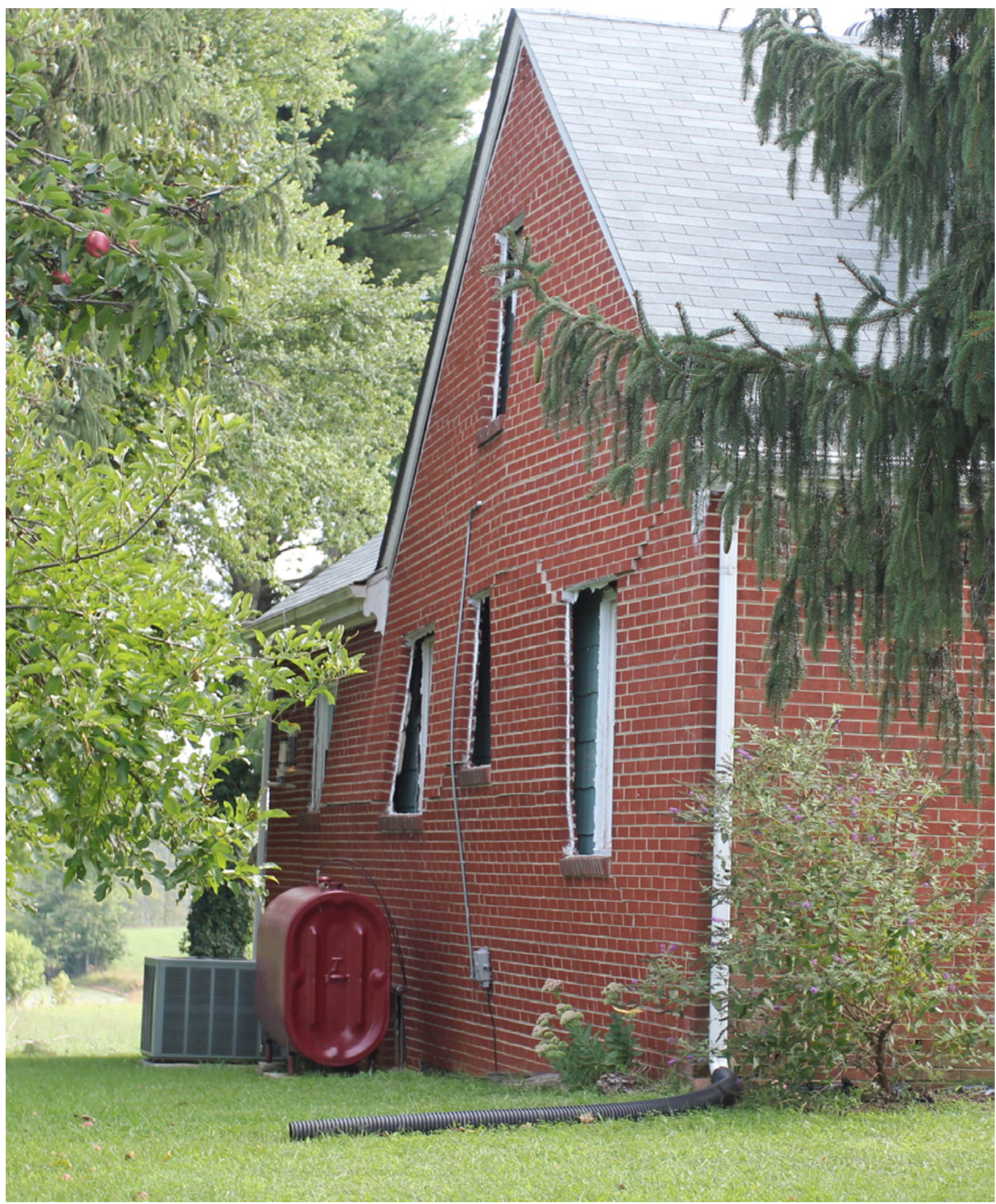

Figure 17. Photograph of a brick wall of a Louisa, Virginia, residence after the August 23, 2011, Mineral, Virginia, earthquake. The wall was damaged in the earthquake and can clearly be seen bowing away from the main structure. The wall collapsed completely a few days after this photo was taken.

\section{Charlottesville and Richmond, Va.}

Buildings in the cities of Charlottesville and Richmond sustained little to no damage from the earthquake. Most structures in the area are of various construction types, from brick and masonry, through wood frame, to reinforced concrete. Still, none of the structures we visited during our field 
inspection was visibly damaged. One gas leak was reported in Charlottesville after the earthquake, prompting closure of several streets (Jones, J., Charlottesville Fire Dept., oral commun., August 2011).

\section{Discussion and Conclusion}

Earthquakes in the Eastern United States are generally felt over a larger area than those of the same magnitude in the Western United States, owing mainly to lower seismic attenuation in the East (Hanks and Johnston, 1992). An $M_{\mathrm{w}}=5.5$ earthquake in the Eastern United States commonly can be felt as far as $500 \mathrm{~km}$ from the epicenter and sometimes can cause damage as far away as $40 \mathrm{~km}$ (Nuttli, 1973; Boore and Atkinson, 1987). This widespread effect was clear during the August 23, 2011, earthquake which was felt as far away as Toronto, Ontario, Canada (850 km north of the epicenter) and which caused damage as far away as Washington, D.C. (150 km north of the epicenter).

The level of damage expected from an $M_{\mathrm{w}}=5.8$ event can be inferred from the MMI rating. According to the USGS Community Intensity Map of the August 23, 2011, earthquake, the maximum MMI was VII (very strong; fig. 4), at which ground shaking causes difficulty to stand, breakage of furniture, and considerable damage to poorly built or badly designed structures. In addition, some chimneys may collapse, windows may break, and masonry walls may be cracked. These maximum MMIs were felt closest to the epicenter, in the towns of Mineral and Louisa, Va. The earthquake occurred at 6-km depth on a north-northeast-striking plane along a reactivated reverse fault in the CVSZ (Earthquake Engineering Research Institute, 2011).

Damage corresponding to an MMI of V was sustained in Richmond and Charlottesville, Va., located 35 to $60 \mathrm{~km}$ from the epicenter. In some houses, local residents reported that items fell off walls and shelves, and heavy furniture was moved. However, no damage to large structures was reported in either city.

The areas surrounding Charlottesville and Richmond sustained MMIs of V (moderate) to VI (strong). An MMI of V corresponds to a situation in which people are frightened, run outdoors, and walk unsteadily and the damage includes broken windows, dishes, and glassware, books falling off shelves, some heavy furniture moving or being overturned, and plaster cracking and(or) falling off.

The earthquake damage documented by our field work is consistent with MMIs of V though VII. Close to the epicenter, the MMI was VI to VII (strong to very strong): residents reported difficulty in standing, and poorly built structures were destroyed, some chimneys collapsed, and windows and masonry walls were cracked and deformed. The most common types of damage were collapsed chimneys (figs. 10, 11, 14) a classic example of an MMI of VII.

Even as far away as Washington, D.C., $135 \mathrm{~km}$ northeast of the epicenter, several buildings sustained structural damage, including the National Cathedral, the Ecuadoran embassy, and the Washington Monument (Achenbach, 2011).

\section{Acknowledgments}

We thank the people of Virginia for their assistance during our fieldwork. We received considerable help from the residents of Mineral and the fire crews of Charlottesville and Louisa County. We are grateful to National Association of Geoscience Teachers (NAGT) advisor Robert Ridky for providing support for this study and to Jack Boatwright and Walter Mooney for their invaluable reviews of the manuscript. Chris Stephens and Patricia McCrory supplied final edits and comments. 


\section{References Cited}

Achenbach, J., 2011, 5.8 Virginia earthquake shakes east coast, rattles residents: The Washington Post, accessed May 23, 2013, at http://www.washingtonpost.com/earthquake-rattles-washingtonarea/2011/08/23/gIQATMOGZJ_story.html.

Bailey, C.M., and Roberts, C., 2000, Physiographic map of Virginia Counties: Williamsburg, Va., College of William and Mary, accessed May 23, 2013, at http://web.wm.edu/geology/virginia/provinces/pdf/va_counties_phys.pdf.

Boore, D.M., and Atkinson, G.M., 1987, Stochastic prediction of ground motion and spectral response parameters at hard rock sites in eastern North America: Bulletin of the Seismological Society of America, v. 77, p. 440-467.

Crone, A.J., De Martini, P.M., Machette, M.N., Okumura, K., and Prescott, J.R., 2003, Paleoseismicity of two historically quiescent faults in Australia; implications for fault behavior in stable continental regions: Seismological Society of America Bulletin, v. 93, no. 5, p. 1913-1934.

Earthquake Engineering Research Institute, 2011, Learning from earthquakes: The $M_{\mathrm{w}} 5.8$ Virginia earthquake of August 23, 2011: Earthquake Engineering Research Institute, accessed May 23, 2013, at http://www.eqclearinghouse.org/2011-08-23-virginia/files/2011/12/EERI-GEER-DRCVirginia-eq-report.pdf.

Hanks, T.C., and Johnston, A.C., 1992, Common features of the excitation and propagation of strong ground motion for North American earthquakes: Seismological Society of America Bulletin, v. 82, p. 1-23.

Hatcher, R. D., Jr., 2004, Regional Geology of North America/Southern and Central Appalachians: Elsevier Publishers, London, Encyclopedia of Geology, p. 72-81.

Johnston, A.C., and Schweig, G.D., 1996, The enigma of the New Madrid earthquakes of 1911-1912: Annual Review of Earth and Planetary Sciences, v. 24, p. 339-384.

Nuttli, O.W., 1973, Seismic wave attenuation and magnitude relations for eastern North America: Journal of Geophysical Research, v. 78, p. 876-885.

Schulte, M., and Mooney, W.D., 2005, An updated global earthquake catalogue of stable continental regions - Reassessing the correlation with ancient rifts: Geophysical Journal International, v. 161, p. 707-721.

U.S. Geological Survey, 2011a, M5.8-Virgina, Tuesday August 23, 20011 -USGS Community Internet Intensity Map: U.S. Geological Survey Web site, accessed September 2011 at http://earthquake.usgs.gov/earthquakes/dyfi/events/se/082311a/us/index.html.

U.S. Geological Survey, 2011b, USGS/SLU Regional Moment Solution [August 23, 2011, Mineral, Virginia, earthquake], U.S. Geological Survey Web site, accessed September 2011 at http://earthquake.usgs.gov/earthquakes/eqarchives/fm/se082311a_rmt.php.

U.S. Geological Survey, 2012, Virginia Seismic Hazard Map: U.S. Geological Survey Web site, accessed August 2012, at http://earthquake.usgs.gov/earthquakes/states/virginia/hazards.php.

Times-Dispatch Staff, 2011, Louisa damage estimate \$70 million: Richmond Times-Dispatch, accessed August 2012, at http://www2.timesdispatch.com/news/2011/aug/31/tdmet01-louisadamage-estimate-70-million-ar-1275161/. 